\title{
IFI16 Gene
}

National Cancer Institute

\section{Source}

National Cancer Institute. IFl16 Gene. NCI Thesaurus. Code C115026.

This gene plays a role in transcriptional regulation, cell differentiation and immune response-mediated programmed cell death. 